\title{
WOMEN AND CONFLICT TRANSFORMATION IN AFRICA
}

\author{
FATUMA AHMED ALI \\ Researcher of the UNESCO Chair for Philosophy of Peace \\ Universitat Jaume I, Castellón
}

\section{INTRODUCTION}

Despite the fact that conflict has portrayed women and girls as victims and actors, their role in conflict transformation is yet to be considered as peace building. This is because, women have always been viewed as "poor victims who need to nurse their wounds» due to the effects of war on them. Therefore, challenges still lay ahead for women peace activists to campaign since without their full participation in conflict transformation and peace processes, the process remains incomplete. In addition, sustainable peace lingers far from being achieved.

Moreover, there are many fascinating examples of women's role in conflict transformation and mobilization against the ravages of war. This not only provides evidence that as human beings they are able to comprehend how our society drives itself to destruction but also how we can organise to stop this devastation. Hence, women have not only manifested their social construction as the "peaceful sex" but have also contributed a great deal in peaceful conflict transformation in many post conflict societies using simple strategies and promoting reconciliation.

Consequently, it can be argued that the role of women in peaceful conflict transformation is one of the untapped resources which exist and could aid to eliminate the suffering caused by havocs of wars. For this reason, we urgently need a fundamental shift from the victim paradigm to peace builder paradigm by involving women in every stage of the peace process.

Furthermore, the challenge to initiate peace is enormous. Nearly 100 conflict situations, primarily civil wars in developing countries, have erupted since $1990^{1}$. The Africa continent is especially hard hit. Formal mechanisms of

1. UMA, Monica Kathina: Unveiling Women as Pillars of Peace: Peace Building in Communities Fractured by Conflict in Kenya, an Interim Report, Management Development and Governance Division Bureau for Development Policy, United Nations Development Programme, 2000. 
conflict transformation and peace making are largely ill equipped to handle the multiplying number of complex and intractable conflicts. Alternatively conflict transformation and peace building frameworks are therefore, necessary. As such, women are increasingly encouraging and supporting conflict transformation and peace building mechanisms. Moreover, women have used both indigenous and western approaches in conflict transformation and peace building. Effectively, women light the candle of peace and pass it on to rest of the society using their innovative strategies in conflict transformation and peace building initiatives.

However, the literature on women's participation in conflict transformation and peace processes takes two approaches. One focuses on their representation and participation at high political levels and in decision-making mechanisms for conflict transformation. The second is a disparate collection on women's grass-roots peace building initiatives. The first approach includes the ongoing debates in international agencies. These discussions of women's participation in decision-making about war and peace predate recent discussions of their role in post conflict reconstruction ${ }^{2}$.

Therefore, in this article I analyse the importance of women in conflict transformation as peacebuilders. In order to grasp the role of women in conflict transformation as peace builders, this article is divided into four sections. The first section addresses the impact of the violent conflict on women; it briefly looks into the role of women in war to understand other reality of women involvement. Highlighted as well is the role of women as peace builders in conflict transformation. The second section analyses the international context with the aim of looking at what has been done internationally to give women access to become peace builders and to transform conflict. Consequently, the third section deals with women's roles and strategies in conflict transformation and peace building. In this section, local strategies used by women as conflict transformation tools are presented. Finally, the fourth section talks about women's contributions to conflict transformation in Africa by narrating how they mobilise for the survival of their societies. This part gives a further analysis of the activities women have undertaken such as the rehabilitation of ex-combatants, disarmament and organizing support group to rebuild their shattered lives. Another important aspect is their involvement in reconciliation which is studied from the point of view of women's participation in traditional justice system such as the Gacaca courts in Rwanda

\section{THE IMPACTS OF THE VIOLENT CONFLICT ON WOMEN}

Prior to discussing women's role in conflict transformation, it is important to highlight the impact of violent conflicts in women's lives. It can be argued that although the exact numbers and gender proportions of killings in war are virtually impossible to determine, the assumption that more men than women

2. Ibid., p. 1. 
are killed in warfare is plausible. However, when war reaches the civilian population, the proportion of female population also rises ${ }^{3}$. Reality is that in contemporary so called "new wars" civilian population makes up $70 \%$ of warrelated victims.

During war, women are targeted specifically because of their main gender role which is maternal. They are subjected to abduction, sexual abuse, rape and all forms of torture. The trauma for female victims in violence continues even when the conflict is over, as they are frequently shunned, ostracized and further stigmatized as a result of violence they have experienced during armed conflict. Women do experience violence much more than men due to their prescribed roles and position in the society. Both men and women are socialised to understand that women are subservient to men. Men also internalise the ideology that they (men) have the right to subjugate women ${ }^{4}$.

The fall of the Berlin Wall and the end of the Cold War for instance, ushered in a new era in the world, an era in which it is not easy to distinguish between combatants and non-combatant, especially in wars where there are no frontlines, no uniforms, no recognized military structure and with new categories of fighters like women and children. The vast majority of armed conflicts either intrastate or interstate conflicts. These conflicts occur in villages, families, ethnicities and race, colour, as well as women's and girl's bodies. The development of efficient war-making technologies in the military industry makes war and militarism extremely deadly, given that technology does not distinguish between combatants and civilians. In fact, civilians are targeted strategically to defeat enemy. Evidently, women and girls constitute the high proportion of the casualties during war and armed conflicts.

Apparently, women's and men's experience of armed conflict takes place in highly varying contexts. In some cases individuals become direct targets of violence, while in others whole communities may be indirectly threatened by insecurity, fear and loss of livelihood. Conflict may be momentary or may continue for years, giving rise to situations of long-term generalised insecurity. Displacement and flight are often obvious consequences, but not consistently so. The impacts of conflict are therefore difficult to categorise and the distinctions made will inevitably be subjective. Although some trends are clearly documented such as demographic changes, changes in marriage practices and sexual division of labour, the long-term social consequences that follow a conflict must be understood in particular contexts. The impact of war on women can be distinguished as such at personal or individual level, at the levels of household and community, and at the broader societal level.

At an individual level, women experience the danger of physical insecurity. For example, during the genocide in Rwanda reportedly 500.000 women were

3. SkJelsbaeK, Inger and Smith, Dan (eds.): Gender, Peace and Conflict, Oslo, International Peace Research Institute (PRIO), 2001.

4. WARSAME, Amina: Queens without Crowns: Somaliland women's changing roles and peace building, Nairobi, SOWRAG/Life \& Peace Institute, Horn of Africa series 4, 2002. 
raped $^{5}$. Increase of domestic violence is another category of danger. On one hand, the impact of the destruction of health services is terrific: after the genocide in Rwanda for instance, $80 \%$ of the women had been infested by venereal diseases. On another hand, there is loss of family members, homes, prospects for the future, as well as the need to adjust to radically new circumstances; all exacerbate the psychological impact of the experience of war, social upheaval and displacement.

Within the household level, family composition changes when large numbers of men and boys are absent. There is a clear trend in a greater proportion of female-headed and child headed households (30\% or more) in conflict and post-conflict situations which results in changes in division of labour. Whether the household is male- or female-headed, there is a strong tendency for women to take on additional productive roles, either because of the absence of men, or because men have lost access to the resources they once controlled. At the community level, conflict may create space to make a redefinition of social relations possible, but in so doing it rather rearranges, readapts or reinforces patriarchal ideologies, rather than fundamentally changing them. At the same time, we should not forget that the consequences of conflict and impact are varied and complex from society to society, and often lead in turn to further various consequences.

Additionally, women suffer in war and armed conflicts in many others ways. These include torture; mutilation (such as in the cases of Sierra Leone and Liberia where people's limbs were cut off), forced prostitution, slavery, assassination/murders, abduction, and forced pregnancies, infected with sexually transmitted diseases such as AIDS/HIV. Women and children are reported to be victims of anti personal landmines. They are forced to take arms, kill and torture. They are detained, humiliated, given inhuman treatment and suffer from fear due to insecurity. In some cases they are sterilised. Consequently, women and children are adversely affected and as consequences the entire society is affected.

Besides, people become vulnerable when they are displaced and disturbed in their daily livelihood. Furthermore, women and children are most vulnerable in this situation based on their special necessities and requirements. The refugee women and girls often face sexual violence both in refugee camps and in «safe» or resettled location. They also face gender discrimination while seeking asylum. They confront many problems related to their biological make up including menstruation, gestation, parturition and lactation. Lack of necessities such as health care, adequate food and rest in the refugee camps impel women and girls into desperate measures such prostitution, illegal trading and joining armed groups for survival purposes ${ }^{6}$.

5. SKJELSBAEK, Inger and SMITH, Dan (eds.): Op. cit., p. 3.

6. TURPIN, Jennifer: "Many faces: women confronting war», in Lois Ann Lorentzen and Jennifer Turpin (eds.): The Women and War reader, New York, New York University Press, 1998, pp. 4-10 


\subsection{The role of women in the war}

Shifting the focus from the impact of violent conflict on women, there are many researches focused on women and men experiences in the battlefields. It follows therefore that women can also be warriors for various reasons. Women are only $2 \%$ in the armed forces nowadays, complying with a certain stereotypes about the roles of women and men. There cannot be unquestioning and fixed notions of masculinity and femininity at a time when gender identities and relations are, as a result of war and armed conflict, in a considerable state of flux. Thus, the role of women in armed conflict and war historically varied from fighting to controlling politics, training troops, accompanying their men in the combats fields, as ambassadors, warriors, negotiators, interpreters, administrators, military advisors, trainer pirates and strategists. Women also cooked, cleaned, carried weapons, gunpowder to the cannons, helped to nurse the wounded, provided water, food, clothing and medical care for the troops. In the $20^{\text {th }}$ century women roles included military intelligence and sabotaging military target. Furthermore, today there are still many women participating and involved directly or indirectly in many armed conflicts and war around the world.

Hence, men are perceived as protectors of the women and family and part of the potential power elite in a future post conflict society and as an embodiment of the enemy, while on the other hand women play different role. They are potential reproducers of the future generations. They are "property" of men and the ones to be protected. The discourse of men as protectors and women as protected is therefore constructed in relation to each other just as or as part of the related construction of masculinity and femininity. By raping the women during war the aim is two-fold in the mind of the perpetuators: humiliation of dignity of the enemy men and undermine the reproduction capacity of the women, which is seen as embodiment of ethnic/national identity ${ }^{7}$.

At the same time, there is not only women as victims but women as a contributors to war: directly as members of military forces, and in less direct ways, such as providing support services to militias, organising logistics and supplies. They may be active in promoting the culture of war by taking part in ritual validations of fighting, by giving their blessing to fighters. However, this article argues that these roles of women in war or military, an institution that is considered traditional/masculine/private are socially constructing women as warriors because they participate following the dominant masculine patriarchal ways of defense. Therefore, there is no feminine way for defence or making war.

7. SKJELSBAEK, Inger: Gendered Battlefield: A Gender Analysis of Peace and Conflict, Oslo, International Peace Research Institute, 1997. 


\subsection{The role of women as peace builders in conflict transformation}

Nevertheless, just as women lend their support to fighting, they may also do the opposite when they consider it right to do so, using what resources they have (including their position as wives and mothers) to ensure that fighting stops and that non-violence is pursued to resolve differences. In recent times, women have been found on the barricades, some defending war and others opposing it. In doing so women are organising: in countries such as Somalia, Uganda and Rwanda, where women have taken on more active roles in national political life and are beginning to gain acceptance from male hierarchies, even though this may be contested by traditionalists and may not yet have led to changed attitudes at grass-roots level ${ }^{8}$.

Women in Africa have not only been affected by violent conflicts but have also been involved actively in conflict transformation. Their activities, which are mainly carried out within the framework of associations, include the development of survival strategies at community level, the reconstruction of community that have been devastated by conflict, lobbying belligerents to lay down their weapons, the rehabilitation and social reintegration of combatants and awareness-raising campaigns aimed at promoting women's participation in decision making processes relating to peace ${ }^{9}$.

\section{INTERNATIONAL CONTEXT}

As a second part of this article, the focus is on how the international context includes women especially in the international agenda on peace. Although, at international level, Beijing conference set the stage for the Security Council's consideration of women and peace in 1995, five years later the progress was observed to be little in regard to women and armed conflict.

On 31 October 2000, the UN Security Council adopted Resolution 1325 which takes up the impact of war on women and girls and women's participation in conflict transformation and sustainable peace-building processes. This resolution establishes that the international community must be sensitive to and take special account of women's vulnerable situation in times of war, and that the UN member states must cooperate to involve women in peace building and conflict-transformation processes by increasing the proportion of women, particularly at decision-making levels, in all peace support operations and supporting local women's peace initiatives. The Resolution also stresses the importance of mainstreaming a gender perspective in all peace support operations. The inclusion of a gender perspective requires that both women and

8. INTERNATIONAL ALERT: Women Building Peace Sharing Know How, London, International Alert, 2003.

9. International Alert and Association of African Women for Research and Development (AAWW): Report on the Workshop on Conflict Transformation in Africa, London, International Alert, 2000. 
men who are to take part in peace support operations have knowledge of and training in the subject ${ }^{10}$.

Two themes dominate the international debate on gender and peacekeeping and peace building: gender balancing and gender mainstreaming. The first means that financial resources and political pressure are used to increase gender equality numerically. The second deals more with content and the final result means that the gender question is well integrated into activity. Gender mainstreaming can be said to stand in contrast with the practice most frequently used where gender questions are marginalised. For example when one or two hours are reserved for these questions during training without letting the perspective affect other relevant parts of the education or training ${ }^{11}$.

At the same time there are opposing views concerning the appropriateness of timing for attempts to build equitable gender relations in post-conflict settings. Some argue that disruption of traditions and communities by conflict open new post -conflict opportunities for women. However, others warn that addressing gender equity in the unstable post-conflict environment is likely to be an exercise in ineffectiveness ${ }^{12}$.

Generally, it must be noted that the lack of progress in the struggle to secure gender equity suggests a new approach to gender mainstreaming at national and sub national levels of implementation. A new model required to have gender roles and power relations become central components of peace processes and ultimately, conflict transformation ${ }^{13}$.

\section{WOMEN'S ROLES AND STRATEGIES IN CONFLICT TRANSFORMATION AND PEACE BUILDING}

Women's strategies in the quest for peace and conflict transformation are challenging and innovative in the way they address societal needs. One of the most cited examples of women's effort in conflict transformation was recorded by Aristophanes, in his play "Lysistrate» ${ }^{14}$. Aristophanes play is based on when the men in the ancient Greek city states were at war. And the despair of the women made the women from various city states to meet and discuss on how to stop their men from fighting each other. Lacking any powerful means at their disposal, they decided to go on a sexual strike against their men until they stopped fighting ${ }^{15}$. Interestingly enough women here used a very powerful and non violent strategy to bring peace to their societies.

10. StrickLAnd, Richard and Duvvury, Mata: Gender Equity and Peace building: From Rhetoric to Reality: Finding the Way (A discussion paper), Washington, DC, International Center for Research on Women, 2003, pp. 29-30.

11. MINISTRY OF DEFENCE OF SWEDEN: Peace Support Operations from Gender Perspective, Stockholm, Edita Norstedts Tryckeri, 2004.

12. StrickLAnd, Richard and DuvvUry, Mata: Op. cit., pp. 29-30.

13. Ibid., pp. 29-30.

14. BROCK-UTNE, Birgit: Educating for Peace: A Feminist perspective, Oxford, Pergamom Press, 1987.

15. Ibid., p. 37. 
In Kenya, the Green Belt Movement (GBM) led by the 2004 Nobel Peace Prize winner Wangari Maathai has played an active role in preservation of natural resources and in enhancing democracy. While it is true that the GBM was started as a purely environmental conservation movement, its activities in promoting social justice through the application of decisive strategies prompted government response at different instances. These strategies included stripping off clothes, a strategy understood by many African cultures as a curse, camping and hunger strike. This strategy was also used by African women during colonial times to voice their discontent regarding the snatching of their lands by the colonial administration. Of course, this tactic was not understood by the colonial administrators because it was not in their cultural context.

Under the leadership of Wangari Maathai, ten women whose sons and husbands had been detained for demanding more democratic right participated in the struggle for their release ${ }^{16}$. By translating a taboo such as women public stripping off into a strategy, women provoked the attention of the government to their course national wide. In response, Wangari was arrested. Despite her arrest, the women refused to disperse and opted to camp at All Saints Cathedral as they waited for the release of their sons and husbands. And as the church remained a source of physical security, the women persisted for one year when their sons and husbands were released and came to celebrate the power of their women and mothers.

Similarly, in 1992 women from Wajir District in Kenya were responsible for starting what in 1995 became the Wajir Peace and Development Committee (WPDC) previously known the Wajir Peace Group (WPG). The WPG successfully intervened in the conflict between different clans of the Kenyan Somali in the Northern Eastern by holding dialogue at all levels of people such as young and old in the society. The WPDC was a reaction to the effect of the collapsed state of Somali in 1991 when Somali clans exported their conflicts in Kenya ${ }^{17}$.

It was women in Wajir who sought ways of minimizing the effect and initially targeted other women as the key operators in the process of diffusing conflicts. Women went door to door convincing the other women not to fuel inter-clan fighting and as a result they formed the Women for Peace Group. Women then targeted the elders and convinced them to form Elders for Peace who would then use their traditional authority to reconcile different parties. Women also targeted religious leaders to preach peace. These groups, with government support, transformed themselves into WPDC in 1995 and have engaged in peace research and mounting peace education in schools. As a result, women social collective role has contributed to their revolutionary change within their societies especially by using local tactics. For example the stripping off clothes strategy has also used by women in other African countries such as

16. KENNEDY, Ferry: "Wangari Maathai: Women and the Environment», in Speak The Truth Power, 2004 in http://www.speaktruthpower.org/defend/profile/profile_07.asp, 28-08-2006.

17. Munene, Macharia: Dimensions of Researching and Promoting Peace in Eastern Africa, Unpublished. 
in Nigeria by the Ogoni women. And in Sierra Leone where in May 2000, for example when the Revolutionary United Front (RUF) flouted the 1999 Lomé accords, a group of elderly women came together and demanded a meeting with Foday Sankoh. Arriving at the RUF compound, they were mistreated and insulted ${ }^{18}$. Frustrated, the women tried a different tactic. They collectively hitched up their skirts, bent over, and bared themselves to Sankoh and his coterie $^{19}$.

In Sierra Leone, such an action by women is the worst curse that can be bought upon anyone and due to this event the Sierra Leonean felt they had an obligation to uphold the women's honor and support the curse ${ }^{20}$. But the women's action also gave people courage to stand up to the RUF. Coinciding with the arrival of the new UN mission and British Special Forces, coupled with subsequent demonstrations, the women's protest was pivotal in the struggle for peace and culminated in Sankoh's arrest

It can therefore be argued that the role of women in conflict transformation does not only focus the times of war but also in times of negative peace. For instance, as participants in promoting social justice, women have used different strategies to address issues affecting the society at large. These issues cover the very basic needs and encompass structural violence as an indirect violence that comes from social structure itself-between human includes exploitation, marginalization and repression ${ }^{21}$.

As a social group, women have been appropriately identified as being propeace. This is because women are highly visible in peace movements. They have been involved in the fight against all sort of social justice and for peace. Examining the different women's peace movement we can further conclude that women across the world have sacrificed their lives for peace, challenged militarism, struggled against social injustice, racism and opposed the development, testing and proliferation of nuclear power. As seen women do contribute to conflict transformation as activists, survivors, voices and community leaders.

\section{WOMEN'S CONTRIBUTIONS TO CONFLICT TRANSFORMATION IN AFRICA}

Finally, as a point of departure, the existence and achievements of women's mobilization during armed conflict to cater for the society shows their potential. For example, for 30 years, the Saharawi women in the refugee camps of

18. Mazurana, Dyan and Carlson, Khristopher: «From Combat to Community: Women and Girls of Sierra Leone", in Hunt Alternatives Fund, 2004, in http://www.peacewomen.org/ resources/Peace_Negotiations/WWPSierraLeone.pdf, 25-05-2005.

19. BOUTA, Tsjeard and others: Gender, Conflict and Development, Washington, D.C, The World Bank, 2005.

20. Ibid., p. 68.

21. Caltung, Johan: Peace by peaceful jeans: Peace and Conflict, Development and Civilisation, Oslo, International Peace Research Institute, 1996. 
Tinduf in Southwest Algeria have proved their potential. They have taken the primary responsibility for building the camp, health services, schools, sanitation, find water and food.

Politically, Saharawi women participate in the struggle for independence of Western Sahara by maintaining links with Saharawi women in the occupied territory while female politicians defend the role of women. Outside the refugee camps they participate in diplomatic campaign for a peaceful solution to their current situation. In a nutshell the activities of Saharawi women in their efforts toward peace making and conflict transformation demonstrate their role socially, academically, diplomatically and politically.

Moreover, women have launched a program of rehabilitation and socialization for ex-combatants, especially child soldiers, during reconciliation and reconstructions period in countries such as Sierra Leone. In other case, the extensive experience of women in practical problem solving, especially in reconciliation, is strengthened due to their good listening, communication skills, willingness and flexibility to compromise. For example, in Rwanda, widows came together in 1997 and set up the Association for Widows of the genocide (AVEGA) with the objective of helping women to deal with the trauma of genocide and give each other support as they tried to rebuild shattered lives. Like so many other self-help and humanitarian organizations created by women, the Association provides psychological and social support and health services to its members ${ }^{22}$.

Furthermore, women presence is also beginning to be felt in the traditional conflict transformation systems such as in the Gacaca courts in Rwanda. The Rwandan government revived an old system of dispute resolution that has largely fallen into disuse, to assist with hearing genocide cases. Gacaca, in its new form, has incorporated important roles for women such as judges ${ }^{23}$. Although many believe that it is too early to evaluate what difference this might make to the outcome but this article argues that the incorporation of women contributes to the reconciliation process through forgiveness and building trust. One of the fundamental inputs of women's participation has been their capacities to listen with compassion, to know how to compensate the affected families and to reunite a divided society by forgiveness.

Also, there have been many cases of women's involvement in disarmament initiatives. For example is the Liberian Women's Initiative (LWI) which was formed in 1994 in response to the lack of progress and the silence of women's voices in the peace talks. ${ }^{24}$ This initiative is open to all women, regardless of ethnic, social, religious or political background. They chose «disarmament be-

22. ReHN, Elizabeth and SirleAf, Ellen Johnson: Women, War and Peace: The Independent Experts' Assessment of the Impact of Armed Conflict on Women and Women's Roles in Peace-building, New York, United Nations Development Fund for Women, 2002.

23. UNRISD: Gender Equity: Striving for Justice in an Unequal World, France, UNRISD, 2005.

24. AHMED, Fatuma: Women and War: Deconstructing the notion of victim and reconstructing their roles as peace builders, Unpublished (Trabajo de investigación doctoral). 
fore elections» as their primary advocacy tool. They are known for their strategies of targeting all parties involved in the peace talks and how they started a programme to assist in the collection of small arms. Although they were never official participants in the peace talks, they proved to be influential consultants during the process and also acted as effective monitors of the process.

\section{CONCLUSION}

This article has presented a comprehensive overview of the importance of women in conflict transformation as peacebuilders which was explained in four sections in order to understand the role of women in conflict transformation as peace builders. The first section addressed the gendered impact of violent conflict on women. It briefly looked into the role of women in war to understand other reality of women involvement and it was argued that depiction of women as warriors was a social construction because there is no feminine way of making war or defense. In the same part, the role of women as peace builders in conflict transformation was also highlighted. In the second part, the international context was analysed to see how the international agenda was including the gender perspective in promoting the role of women in conflict transformation and peace building. Hence the third section dealt with women's roles and strategies in conflict transformation and peace building. Here the local strategies used by women as conflict transformation tools were outlined. And finally, the fourth section talked about women's contributions to conflict transformation in Africa by narrating the activities of women such as mobilizing for the survival of their societies, participating in rehabilitation of ex-combatants, disarmaments and organising support group to rebuild their shattered lives. As well, their involved in reconciliation through their participation in traditional justice system such as the Gacaca in Rwanda was studied.

Despite the resolutions undertaken by various International institutions and commitments imposed on the individual state, example of many countries show that women are still outside of the negotiation and peace building process as well as decision making. The women capacity and resources, in other words, not are applied. However, they are very much present in conflict transformation through their roles as peace builders.

From this perspective, it is time to establish a system of accountability within Member States and within the United Nations on the implementation of Security Council resolution 1325, to oblige state to undertake nationwide actions. And also to deconstruct the predominant notion of women as poor victims who wars should be fought to protect them. Women capacities and abilities should be recognised and encouraged in order to create a peaceful society. It can be actions on conflict transformation and education campaigns that include strategies to target marginalised members of society such as women. It is necessary to sensitize men and women in issues related to gender based violence (GBV). Government and local NGOs should administer communitybased psychosocial programs designed to respond to the needs of women during and the in the aftermath of conflict. 
However, women's contributions to conflict transformation in Africa are either largely ignored by official policy-making structures, which they therefore cannot influence, or invisible. In general, men and women have different experiences of armed and post-conflict situations. Furthermore in most cases, only men's more visible life experiences and contributions features in analyses relating to conflicts and the mechanisms put in to resolve them. Therefore, women should be given more space to use their experience in conflict transformation. 